\title{
Loss of Octarepeats in Two Processed Prion Pseudogenes in the Red Squirrel, Sciurus vulgaris
}

\author{
Ole Madsen • Timothy T. Kortum • \\ Marlinda Hupkes • Wouter Kohlen • \\ Teun van Rheede $\cdot$ Wilfried W. de Jong
}

Received: 12 July 2010/Accepted: 8 September 2010/Published online: 28 September 2010

(C) The Author(s) 2010. This article is published with open access at Springerlink.com

\begin{abstract}
The $N$-terminal region of the mammalian prion protein (PrP) contains an 'octapeptide' repeat which is involved in copper binding. This eight- or nine-residue peptide is repeated four to seven times, depending on the species, and polymorphisms in repeat number do occur. Alleles with three repeats are very rare in humans and goats, and deduced PrP sequences with two repeats have only been reported in two lemur species and in the red squirrel, Sciurus vulgaris. We here describe that the red squirrel two-repeat $\operatorname{PrP}$ sequence actually represents a retroposed pseudogene, and that an additional and older processed pseudogene with three repeats also occurs in this species as well as in ground squirrels. We argue that repeat numbers may tend to contract rather than expand in prion retropseudogenes, and that functional prion genes with two repeats may not be viable.
\end{abstract}

Keywords Prion protein - PrP - Octarepeat .

Protein evolution · Pseudogene

Teun van Rheede-Deceased May 21, 2003.

Electronic supplementary material The online version of this article (doi:10.1007/s00239-010-9390-7) contains supplementary material, which is available to authorized users.

O. Madsen · T. T. Kortum · M. Hupkes · W. Kohlen ·

T. van Rheede . W. W. de Jong

Biomolecular Chemistry, 271 Nijmegen Center of Molecular

Life Sciences, Radboud University, P.O. Box 9101, 6500,

HB, Nijmegen, The Netherlands

O. Madsen ( $\square)$

Animal Breeding and Genomics Centre, University

of Wageningen, P.O. Box 338, 6700, AH, Wageningen,

The Netherlands

e-mail: ole.madsen@wur.nl

\section{Introduction}

The prion protein ( $\mathrm{PrP})$ is a plasma membrane glycoprotein of essentially unknown function (Steele et al. 2007), which has been implicated in disparate processes, such as copper binding, anti- and pro-apoptotic activities, redox homeostasis, neuron formation and myelin maintenance (Aguzzi et al. 2008; Bremer et al. 2010). Misfolded isoforms of PrP mediate the intra- and inter-species transmission of the mammalian prion diseases (transmissible spongiform encephalopathies, TSEs) (Kovacs and Budka 2009). Copper binding to PrP occurs extracellularly at the $N$-terminal domain, which in most mammals contains five or six repeats of a peptide of eight or nine residues with the consensus sequence $\mathrm{P}(\mathrm{Q} / \mathrm{H}) \mathrm{GGG}(\mathrm{G} /-)$ WGQ (Wopfner et al. 1999; van Rheede et al. 2003; Acutis et al. 2007). This region can bind up to one $\mathrm{Cu} 2^{+}$ ion per repeat (Viles et al. 2008; Guerrieri et al. 2009), but there is still no generally accepted role for the binding of copper to PrP (Davies and Brown 2008). The repeat region modulates prion replication and pathogenicity (Flechsig et al. 2000), is involved in the protective effect against oxidative stress (Mitteregger et al. 2007; Malaise et al. 2008), and in PrP aggregation upon copper binding (Yu et al. 2008).

Mammals homozygous for four or seven repeats also occur (van Rheede et al. 2003; Kim et al. 2008; Rongyan et al. 2008; Martin et al. 2009). In humans, which normally have five repeats, a few families are known in which alleles with seven to even fourteen repeats are associated with atypical cases of hereditary prion disorders (CreutzfeldtJakob and Gerstmann-Sträussler-Scheinker; Kovacs and Budka 2009). Heterozygosity for four repeats occurs at a frequency of $\sim 1 \%$ and is not associated with prion disease susceptibility (Jeong et al. 2004; Bishop et al. 2009), but 
might be related to familial Alzheimer's and Parkinson's disease (Perry et al. 1995; Wang et al. 2009). Heterozygosity for three repeats has been reported in two patients with a rapidly progressing dementia (Beck et al. 2001) and Creutzfeldt-Jakob disease (Capellari et al. 2002), respectively. On the other hand, goats heterozygous for a threerepeat allele appeared more resistant to prion infectivity (Goldmann et al. 1998). There are only two reports of PrP deletion mutants with two repeats. Heterozygosity for a 2- and a 5-repeat allele was reported in two specimens of different species of lemurs which are known to be particularly susceptible for TSE (Gilch et al. 2000). A similar apparent heterozygosity has been reported in a red squirrel, Sciurus vulgaris (van Rheede et al. 2003). Interestingly, five patients from rural Kentucky with probable or definite Creutzfeldt-Jakob disease had a history of eating squirrel brains (Berger et al. 1997), and consuming squirrel brains has been proposed as a serious risk (Sekercioglu 2004). One might wonder whether this relates to the presence of a two-repeat PrP in squirrels.

If the two-repeat allele is more common in lemur and squirrel populations, one would expect the occurrence of two-repeat homozygotes, unless these are lethal. Lethality could be envisaged, considering the role of the intact repeat region in copper binding, and the possibly increased susceptibility for TSE. If viable homozygotes were found, this would challenge the functional and structural importance of the repeat region. This paper describes the search for squirrels homozygous for the two-repeat allele of the prion protein gene, PRNP. However, it turned out that the two-repeat $P R N P$ sequence in squirrel actually represents a retroposed pseudogene rather than an allele of the functional gene. In addition, during this study a second prion retropseudogene, with three repeats, was found in squirrel.

\section{Materials and Methods}

\section{Sampling of Squirrel Material and DNA Isolation}

Samples of tissue (liver or ear tips) or genomic DNA were obtained from Eurasian red squirrels ( $S$. vulgaris) from various localities in the Netherlands, from Germany (Dresden), Spain (Madrid), Italy (Valfurva), Wales (Anglesey) and Russia (Primorsky Krai, Eastern Siberia). Liver was obtained from a Japanese squirrel (Sciurus lis) and genomic DNA from a grey squirrel (Sciurus carolinensis). Tissue samples were either stored at $-20^{\circ} \mathrm{C}$ or preserved in $95 \%$ ethanol. Genomic DNA was extracted using the Promega Wizard ${ }^{\circledR}$ Genomic DNA purification System, following the manufacturer's protocol.
Amplification and Sequencing of Squirrel Prion Genes

Prion genes were amplified using three different primer combinations, named 'long', 'short' and 'long1' (Table S1). The 'long' primer set (Prp_for1 and Prp_rev1) was identical to the primer set used to amplify mammalian PRNP sequences by van Rheede et al. (2003), in which red squirrel yielded two PCR products of 642 and $720 \mathrm{bp}$, for the 2- and 5-repeat allele, respectively. The 'short' primer set was a combination of the original forward primer (Prp_for1) and a primer located just after the repeat region in squirrel PRNP (PrpS2_rev) (van Rheede et al. 2003). The 'short' combination resulted in PCR fragments of 226 and $304 \mathrm{bp}$ in red squirrels. The primer set 'long1' (PrpSq_for and PrpSq_rev) was specifically developed for amplifying the squirrel PRNP gene, and resulted in fragments of 540 and $618 \mathrm{bp}$.

All PCR were performed with the Expand High Fidelity PCR system (Roche) and contained 50-100 ng genomic DNA or $\sim 10 \mathrm{ng}$ cDNA, $200 \mathrm{mM}$ dNTP, 50-100 pmol of each primer, 1.5-2 mM MgCl2, $1 \mathrm{M}$ betain (optional) and 1.75 U Expand High Fidelity Enzyme mix in a final volume of $50 \mu \mathrm{l}$. The following PCR program was used: $2 \mathrm{~min}$ at $94^{\circ} \mathrm{C} ; 35$ cycles of $15 \mathrm{~s}$ at $94^{\circ} \mathrm{C}, 1 \mathrm{~min}$ at $48-62^{\circ} \mathrm{C}$ (mostly $58^{\circ} \mathrm{C}$ was used) and $1 \mathrm{~min}$ at $72^{\circ} \mathrm{C}$ and a final step of $10 \mathrm{~min}$ at $72^{\circ} \mathrm{C}$.

The PCR products were purified from 1\% agarose gels using the GFX ${ }^{\mathrm{TM}}$ PCR DNA and Gel Band Purification Kit (GE Healthcare). Gel-extracted PCR products were sequenced directly with one of the PCR primers, mostly the forward primer, to determine the number of repeats. PCR products of $S$. lis and a $S$. carolinensis were sequenced with both PCR primers to determine the complete amplified sequence. Sequence reactions were performed using Big Dye fluorescent technology, and run on an ABI 3730 96-capillary sequencer (Applied Biosystems).

New sequences determined in this study have been deposited in the EMBL Nucleotide Database under the accession numbers FN678793-FN678795.

\section{Flanking PCR}

Multiple attempts were made to amplify the unknown $5^{\prime}$ and $3^{\prime}$ flanking sequences of the 2- and 5-repeat red squirrel PRNP sequences, applying the 'Flanking PCR' method as described by Sørensen et al. (1993) and van Rheede et al. (2003). The biotinylated primers PrpSqbio_rev and PrpSqbio_for (Table S1) were used in the first round PCR for amplifying the $5^{\prime}$ and $3^{\prime}$ flanking sequences, respectively. The PrpSqbio_rev primer was positioned $3^{\prime}$ to the repeat region, so that it could be determined whether the 2- or 5-repeat flanking sequence had been amplified. With 
these primers we only succeeded in determining the $5^{\prime}$ flanking sequence of the two-repeat gene.

\section{RNA Isolation and RT-PCR}

Total RNA was isolated from red squirrel whole brain tissue using GibcoBRL Trizol ${ }^{\circledR}$ reagent according to the manufacturer's protocol. Isolated RNA was dissolved in DEPC-treated water and stored at $-20^{\circ} \mathrm{C}$ until use. Before cDNA synthesis any remaining DNA was removed by treating the RNA with 5 units of RNase-free DNase per $\mu \mathrm{g}$ of RNA for $15 \mathrm{~min}$ at $37^{\circ} \mathrm{C}$ followed by $10 \mathrm{~min}$ at $70^{\circ} \mathrm{C}$. The reverse transcriptase reaction was performed using the first-strand cDNA synthesis kit for RT-PCR (AMV; Roche Applied Science) according to the manufacturer's instructions, with $1 \mu \mathrm{g}$ of DNA-free total RNA and oligo-p(dT) 15 primers. PCR was done on $2 \mu \mathrm{l}$ of the synthesized cDNA using the squirrel specific primer combination 'long1' and PCR conditions as described above. Possibly remaining contamination with genomic DNA was assessed by performing first-strand cDNA synthesis with and without reverse transcriptase.

Sequence Retrieval, Alignment and Phylogenetic Analyses

The NCBI and Ensembl databases (as on 10 Jan 2010) were searched for additional sciurid prion sequences. In the Genbank database one PRNP gene of the ground squirrel Spermophilus tridecemlineatus (acc. nr. BN000993.2) was found, and from the EST database two PRNP ESTs of the ground squirrel Sp. tridecemlineatus and four of the related Spermophilus lateralis were retrieved. These sequences all have four repeats and apparently correspond with the normal PRNP gene of the two species. BLAST/BLAT searches with the red squirrel 2-, 3- and 5-repeat PRNP sequences and with the Sp. tridecemlineatus PRNP gene and EST sequences against sciurid genomic sequences revealed two PRNP-like sequences in the Sp. tridecemlineatus genome (acc. nr. AAQQ01175405), one corresponding with the four-repeat EST and the other with a three-repeat pseudogene (acc. nr. AAQQ01193410).

The eight available sciurid $P R N P$ nucleotide sequences were aligned with ClustalW2 (http://www.ebi.ac.uk/Tools/ clustalw2/index.html) and manually adjusted for optimal alignment with GeneDoc (v 2.6.002). After removal of the repeat sequences and sites missing in more than two of the eight sequences, the remaining 479-bp alignment (corresponding with positions $120-153$ and 232-667 of the red squirrel 5r PRNP sequence) was used for phylogenetic analysis. An unrooted ML tree was obtained with PhyML v3.0 (Guindon and Gascuel 2003), using K80 as the best fitting model of sequence evolution as indicated with
jModeltest (v. 0.1.1) (Posada 2008). Statistical nodal support was estimated by 100 non-parametric bootstrap replicates.

\section{Results}

We began our search for animals homozygous for the tworepeat $P R N P$ allele by amplifying the $P R N P$ gene from 27 red squirrels from all over the Netherlands. Amplification was done with two primer sets: the 'short' squirrel specific primer set should amplify fragments of 226 and 304 bp for the 2- and 5-repeat PRNP alleles, respectively, and the 'long' primer set fragments of 642 and 720 bp. Surprisingly, all 27 squirrels yielded the same patterns. The short primer pair revealed the two expected bands and a third band of intermediate size (Fig. 1a, lanes 1 and 2), and the long primer pair gave the two bands corresponding to the 2- and 5-repeat bands as originally observed by van Rheede et al. (2003) (Fig. 1a, lanes 3-7). In other mammals only the long primer pair resulted in successful amplification, and yielded a single band, corresponding with five(human, rhinoceros, elephant) or six-(tenrec) repeats (Fig. 1a, lanes 8-11). The fact that all the squirrels displayed the 2- and 5-repeat bands strongly indicated that these bands represent two different $P R N P$ gene loci, rather than alleles.

Sequencing of the PCR products confirmed that the $2 \mathrm{R}$ and $5 R$ bands in lanes 1-7 of Fig. 1a corresponded with the 2- and 5-repeat $P R N P$ sequences originally reported by van Rheede et al. (2003) (S. vulgaris $\mathrm{r} 2$ and $\mathrm{r} 5$ in Fig. 2). In some of the red squirrels single base heterozygosity was observed in both the $\mathrm{r} 2$ and $\mathrm{r} 5$ sequences (Fig. 3), which further confirmed that $\mathrm{r} 2$ and $\mathrm{r} 5$ represent two different PRNP gene loci. In addition to the 2- and 5-repeat sequences, the $3 \mathrm{R}$ middle band in lanes 1 and 2 of Fig. 1a turned out to represent a $P R N P$-like sequence with three repeats ( $S$. vulgaris $\mathrm{r} 3$ in Fig. 2). The presence of an inframe stop codon and a frame-shift mutation in the displayed sequence identifies it as a pseudogene. A database search with this sequence revealed a homologous $\mathrm{r} 3$ PRNP pseudogene in the ground squirrel $S$. tridecemlineatus (Fig. 2). The presence of several synapomorphous mutations indicates that the $3 \mathrm{r}$ pseudogenes in the two species are orthologs.

Apart from the number of repeats, the 2- and 5-repeat $P R N P$ coding sequences of the red squirrel differ at only three synonymous and one non-synonymous sites. The corresponding genes must thus be the products of a relatively recent duplication event. To assess whether this duplication is present in Eurasian red squirrels throughout their distribution range, and in related squirrel species, we amplified the PRNP gene sequences from red squirrels from 


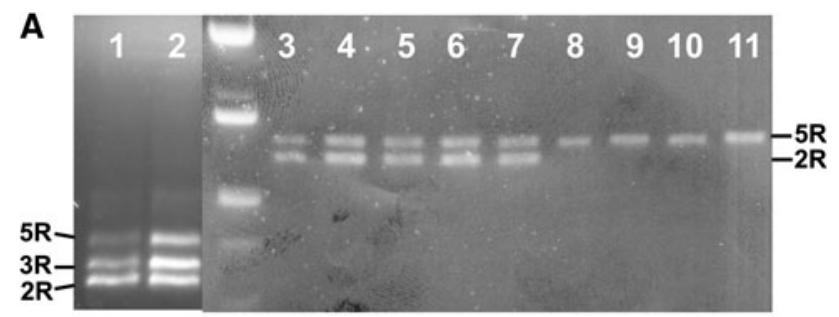

B

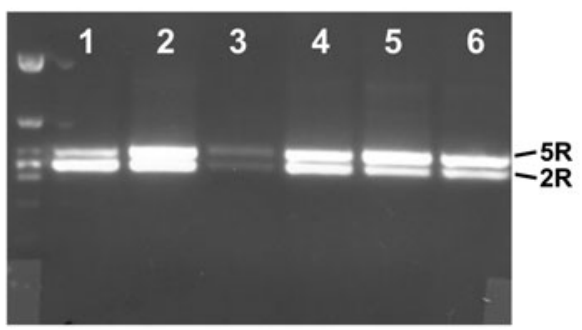

C
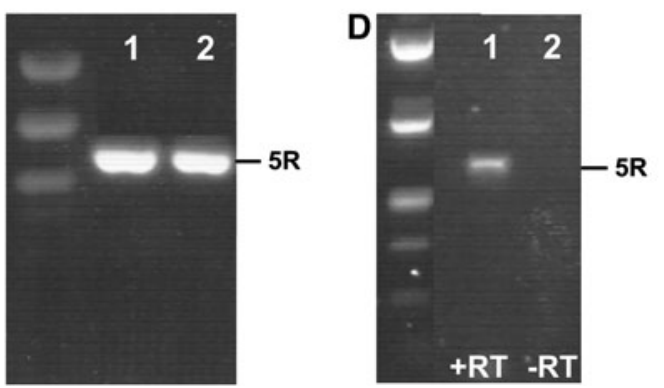

Fig. 1 PCR amplification with $P R N P$-specific primers on samples of genomic DNA $(\mathbf{a}-\mathbf{c})$ and total brain cDNA (d) resolved on $1 \%$ agarose gels. In panel a, lanes 1 and 2 were amplified with the 'short' primer pair, all other lanes with the 'long' primer pair; in panels b, c and $\mathbf{d}$ the 'long1' primer pair was applied (see 'Materials and Methods'). All PCR products were sequenced to determine the number of repeats. $2 \mathrm{R}, 3 \mathrm{R}$ and $5 \mathrm{R}$ correspond with the presence of 2 , 3 and 5 (or 6 in tenrec) repeats. a Lanes 1-7, red squirrels (S. vulgaris) from different localities in the Netherlands; lane 8, human (Homo sapiens); lane 9, black rhino (Diceros bicornis); lane 10, Indian elephant (Elephas maximus); lane 11, tenrec (Tenrec ecaudatus). b Lanes 1-6, red squirrels ( $S$. vulgaris) from Germany, Spain, Wales, Italy, Eastern Siberia and the Netherlands, respectively. c Lane 1, grey squirrel ( $S$. carolinensis); lane 2, Japanese squirrel ( $S$. lis). d cDNA from red squirrel ( $S$. vulgaris) brain; $+R T$ and $-R T$ indicates the presence or the absence, respectively, of reverse transcriptase during cDNA synthesis

different Eurasian locations, as well as from two supposed close relatives, the North American grey squirrel (S. carolinensis) and the Japanese squirrel ( $S$. lis) (Oshida and Masuda 2000; Grill et al. 2009). It turned out that the 2R and $5 \mathrm{R}$ bands were present in all investigated red squirrels (Fig. 1b), while the two other squirrel species only had the $5 \mathrm{R}$ band (Fig. 1c). The identity of the amplification products of $S$. carolinensis and $S$. lis was again confirmed by sequencing (Fig. 2). It is thus most likely that the PRNP gene duplication occurred in the red squirrel lineage, after its divergence from the other two squirrel species, but before the geographic dispersal of the red squirrels.
Given the uninterrupted open reading frame of the red squirrel 2r PRNP gene, it was expected that it would be expressed next to the $5 \mathrm{r}$ gene. However, RT-PCR with $P R N P$-specific primers on squirrel brain cDNA yielded only a single band with the expected size of the $5 \mathrm{r}$ product (Fig. 1d). This indicated that the 2r PRNP gene is not transcribed in the brain and may in fact be a pseudogene. To further assess this possibility, we performed $5^{\prime}$-flankingPCR on the 2r PRNP gene. The 5' UTR sequence aligns well with the corresponding sequences of the mouse $P R N P$ cDNA and with ground squirrel PRNP ESTs retrieved in the databases (Fig. 4), and thus established the absence of the two introns that are normally present in the rodent PRNP gene. This characterizes the $2 \mathrm{r}$ genomic PRNP sequence as a retroposed pseudogene. Unfortunately, no sequences could be obtained to assess the presence of other characteristics of such processed pseudogenes, i.e., flanking repeats and a $3^{\prime}$ poly- $\mathrm{T}$ track. We did not perform flanking-PCR on the $3 \mathrm{r}$ PRNP pseudogene of the red squirrel, but the available sequence data of the orthologous $3 \mathrm{r}$ pseudogene of Sp. tridecemlineatus also shows the absence of introns (Fig. 4).

A phylogenetic analysis of all available squirrel $P R N P$ gene and pseudogene sequences confirms that the $2 \mathrm{r}$ pseudogene of $S$. vulgaris most likely originated after the divergence of this species from the two other Sciurus species (Fig. 5). The tree also confirms that the $3 \mathrm{r}$ pseudogenes of $S$. vulgaris and $S p$. tridecemlineatus are orthologs, and have a much older origin. This 3r PRNP pseudogene might therefore be present in other sciurid rodents as well.

\section{Discussion}

Reports that $P R N P$ alleles with two repeats occur in lemurs (Gilch et al. 2000) and red squirrel (van Rheede et al. 2003) might imply that prion proteins with only two repeats can be functionally viable. It is therefore important that we here demonstrate that the squirrel two-repeat $P R N P$ sequence actually represents a non-expressed retroposed pseudogene. This not only means that any concerns about consuming squirrel brains (Berger et al. 1997; Sekercioglu 2004) can not be related to the expression of a two-repeat PrP, but, more importantly, also raises interesting questions about prion structure, function and evolution. In the case of the reported lemur two-repeat $P R N P$ genomic sequence, it can not be decided from the available data whether it is actually expressed, or whether it shows any further differences with the lemur five-repeat $P R N P$ sequence (Gilch et al. 2000). Since the lemur two-repeat $P R N P$ sequence reportedly occurred in two individuals from different genera, it might be expected to be a more common feature in lemurs. We 


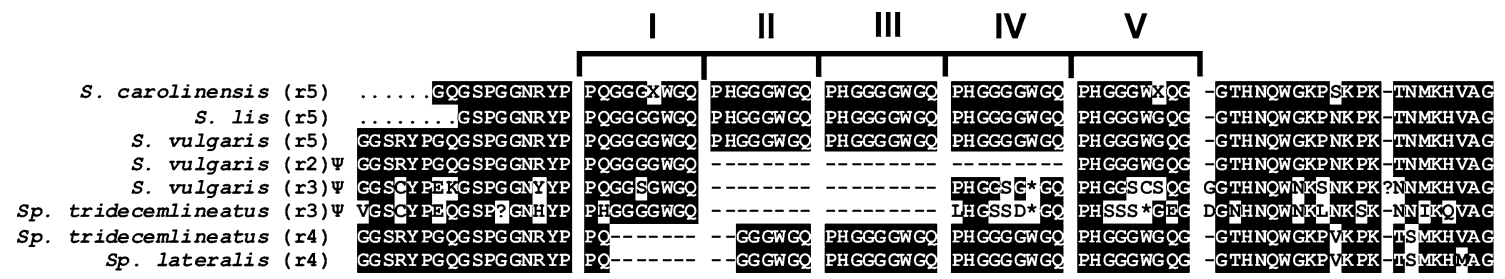

Fig. 2 Alignment of the deduced repeat regions in PrP of grey squirrel ( $S$. carolinensis), Japanese squirrel ( $S$. lis), Eurasian red squirrel (S. vulgaris), thirteen-lined ground squirrel (S. tridecemlineatus) and golden-mantled ground squirrel (S. lateralis). PrP sequences of grey squirrel, Japanese squirrel and Eurasian red squirrel were deduced from sequenced PCR products (see Fig. 1), whereas the ground squirrel PrP sequences were extracted from public databases as either genomic (Sp. tridecemlineatus $r 3$ and $r 4$ ) or EST sequences (Sp. lateralis $r 4$ ). $r 5, r 4, r 3$ and $r 2$ indicate the number of repeats
$(I-V)$ in the different PrP sequences; dotted line, missing data; $X$, ambiguous amino acid; asterisk, stop codon; question mark, out-offrame deletion; dashed line, indel; psi, pseudogene. The consensus sequence is white-in-black. Accession numbers of the sequences used are: S. carolinensis r5, FN678793; S. lis r5, FN678794; S. vulgaris r5, AY133037; S. vulgaris r2, AY133038; S. vulgaris r3, FN678795; Sp. tridecemlineatus r3, AAQQ01193410; Sp. tridecemlineatus r4, AAQQ01175405; and Sp. lateralis r4, CO73759
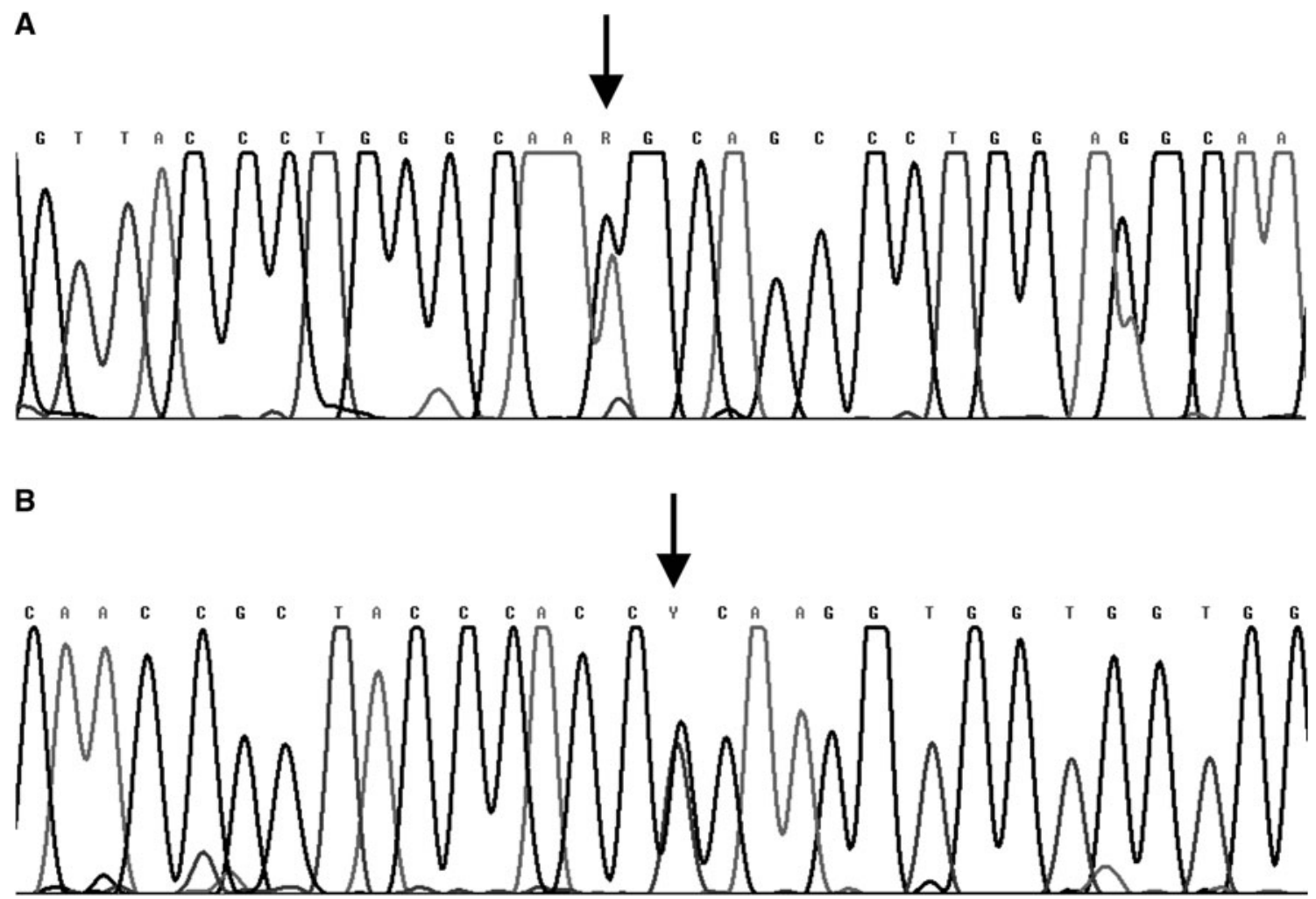

Fig. 3 Examples of single base pair heterozygosity (arrows) in 5-repeat (a) and 2-repeat (b) red squirrel sequences

therefore attempted to retrieve and analyse the nature of such a two-repeat PRNP sequence in six lemur species, including one from the same genus Eulemur as studied by Gilch et al. (2000). However, we have been only able to amplify five-repeat $P R N P$ sequences, and did not find any two-repeat sequence, using a variety of primers and PCR conditions. It thus remains uncertain whether a two-repeat PrP protein actually exists in lemurs, and whether such a $\operatorname{PrP}$ is viable at all.

The most interesting observation in this study is that the two PRNP pseudogenes in $S$. vulgaris have only two and three repeats, rather than the original five. Mammalian PRNP alleles with three repeats have only rarely been reported (Goldmann et al. 1998; Beck et al. 2001; Capellari et al. 2002), and the existence of functional alleles with two repeats has not been documented at all. Is such loss of repeats a more common phenomenon in PRNP pseudogenes? Unfortunately, very few $P R N P$ pseudogenes can be retrieved in the databases and the literature. We performed searches for $P R N P$-like sequences in 35 mammalian genomic resources present in the Ensembl and Genbank databases but never recovered more than a single and 


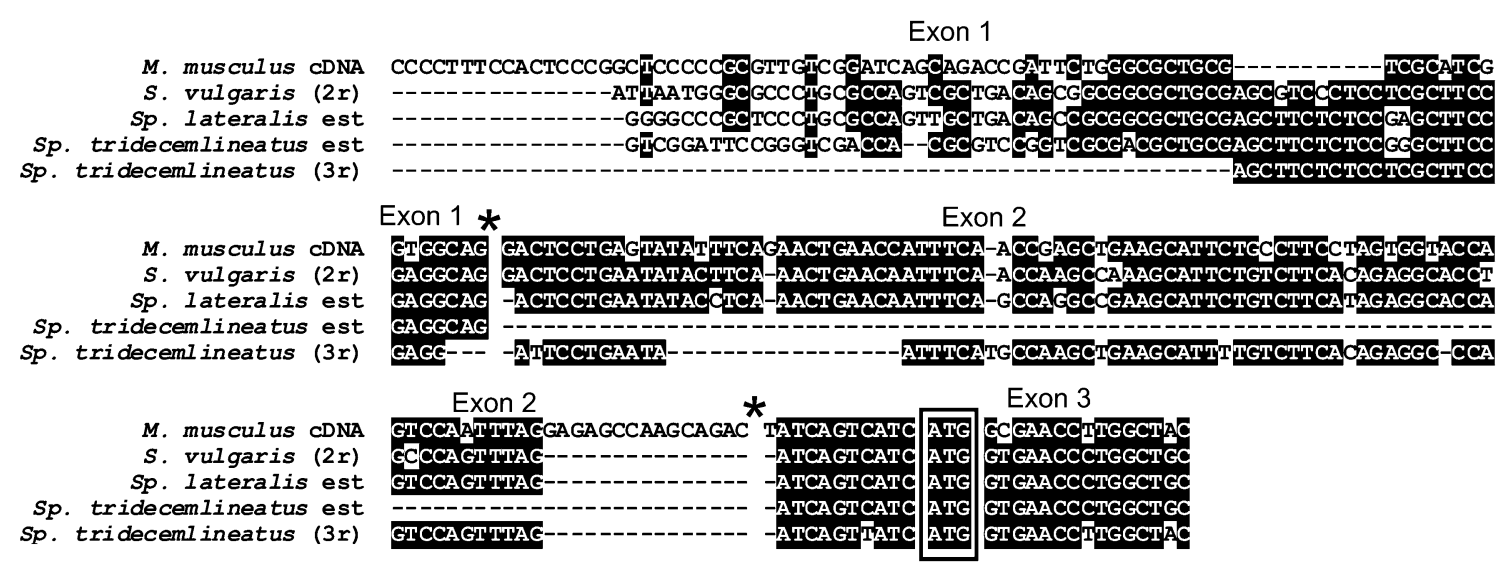

Fig. 4 Alignment of the $5^{\prime}$ flanking sequence of the 2-repeat PRNP pseudogene of red squirrel ( $S$. vulgaris $2 \mathrm{r}$ ) with the prion cDNA sequence of mouse (M. musculus; acc. nr. BC032085), prion EST sequences of thirteen-lined ground squirrel (Sp. tridecemlineatus; EL772736) and golden-mantled ground squirrel (Sp. lateralis; CO739249), and with the $5^{\prime}$ flanking sequence of the 3-repeat PRNP

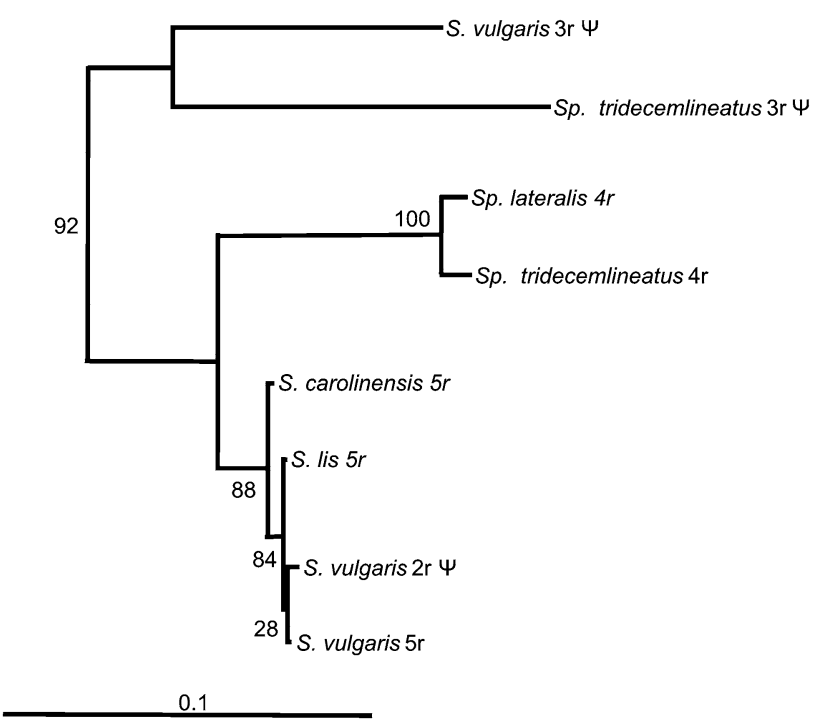

Fig. 5 Unrooted maximum likelihood tree $(-\ln \mathrm{L}=1191.87880)$ based on a 479-bp alignment of the different squirrel PRNP sequences. Bootstrap support values are indicated. The bar corresponds with 0.1 substitutions per site. $2 r, 3 r, 4 r$ and $5 r$ indicates the number of repeats; psi, pseudogenes. Accession numbers of the used sequences are given in the legends of Fig. 2

apparently normal $P R N P$ gene per species, apart from the 3r PRNP pseudogene of Sp. tridecemlineatus, which is in fact the orthologue of the $S$. vulgaris $3 \mathrm{r}$ PRNP pseudogene (Fig. 5). In the literature two additional PRNP pseudogenes have been reported. The anteater (Cyclopes didactylus) has a PRNP pseudogene with several frameshift and nonsense mutations (van Rheede 2003; acc. nr. AF545183). The deduced protein sequence is $66 \%$ identical to the functional $\mathrm{PrP}$, and has only three repeats, against four or five in the functional anteater PrP. It is not known whether this is a pseudogene of thirteen-lined ground squirrel (Sp. tridecemlineatus; AAQQ01193410). Asterisks indicate the positions of the two introns in the mouse PRNP gene; the start codon is boxed. The absence of exon 2 in the Sp. tridecemlineatus EST is probably the result of exon skipping, as has also been reported for the mouse PRNP transcript (Haigh et al. 2007)

retroposed or a duplicated pseudogene. In mule deer (Odocoileus hemionus) and white-tailed deer (Odocoileus virginianus) a retroposed $P R N P$ pseudogene has been characterized, apparently orthologous in the two species (Brayton et al. 2004; O'Rourke et al. 2004). This pseudogene still has an open reading frame, and the deduced amino acid sequence differs at only one position $(138 \mathrm{~S} \rightarrow \mathrm{N})$ from that of the corresponding functional PrP. The functional PRNP gene has five repeats in these deer species, while the pseudogene has alleles with five or six repeats.

Thus, in the four retrieved independent instances of PRNP pseudogene formation in mammals, the repeat number has in two cases been reduced to three, and in one case to two, in sharp contrast to the extreme scarcity or absence of such contractions in case of functional PRNP genes. If this observation may be generalized, it raises the question why such repeat contraction readily occurs in PRNP pseudogenes, but not in the functional gene. Expansion and contraction of repeats is a frequent mutational process in the eutherian PRNP gene. The mechanisms involved can be unequal crossing-over and replication slippage, and contraction would be expected to be as likely to occur as expansion (Collinge 2001). The fact that the repeat number in functional $P R N P$ genes is maintained between four and seven, depending on the species, strongly suggests that higher but also lower repeat numbers are deleterious. In the case of repeat numbers higher than seven this is clearly related to increased susceptibility for TSE (Stevens et al. 2009). Why reduction to three and certainly two repeats apparently is selectively deleterious is perhaps more difficult to understand in view of the fact that PrP knockout mice have no obvious 
phenotype (reviewed by Steele et al. 2007), and PrP knockout mice transgenic for PrP without the repeat region are apparently healthy (Flechsig et al. 2000). However, PrP is a well-conserved protein in mammals, indicating the importance of maintaining its structural and functional integrity (e.g., Wopfner et al. 1999; van Rheede et al. 2003; Rongyan et al. 2008; Premzl and Gamulin 2009). The expression of a PrP with three and especially two repeats might frustrate pathways and processes in which PrP is normally involved, most likely relating to its copper binding properties, and eventually making it evolutionarily disadvantageous.

Acknowledgments We are very grateful to Mieke Holtslag (Squirrel Rescue Centre, De Meern, The Netherlands) for providing the Dutch red squirrel samples. We also like to thank Drs Rob Ogden, Juan Carlos Illera, Luc Wauters, Alexei Kryukov and Anna Hundsdörfer for providing the samples of Welsh, Spanish, Italian, Russian and German red squirrels, respectively. Samples of $S$. lis and $S$. carolinensis DNA were kindly provided by Drs Noriko Yaekashiwa and Scott Steppan, respectively. We thank Dr. Guido Kappé for useful bioinformatical suggestions.

Open Access This article is distributed under the terms of the Creative Commons Attribution Noncommercial License which permits any noncommercial use, distribution, and reproduction in any medium, provided the original author(s) and source are credited.

\section{References}

Acutis PL, Peletto S, Grego E, Colussi S, Riina MV, Rosati S, Mignone W, Caramelli M (2007) Comparative analysis of the prion protein $(\mathrm{PrP})$ gene in cetacean species. Gene 392:230-238

Aguzzi A, Baumann F, Bremer J (2008) The prion's elusive reason for being. Annu Rev Neurosci 31:439-477

Beck JA, Mead S, Campbell TA, Dickinson A, Wientjens DP, Croes EA, van Duijn CM, Collinge J (2001) Two-octapeptide repeat deletion of prion protein associated with rapidly progressive dementia. Neurology 57:354-356

Berger JR, Weisman E, Weisman B (1997) Creutzfeldt-Jakob disease and eating squirrel brains. Lancet 350:642

Bishop MT, Pennington C, Heath CA, Will RG, Knight RS (2009) PRNP variation in UK sporadic and variant Creutzfeldt Jakob disease highlights genetic risk factors and a novel non-synonymous polymorphism. BMC Med Genet 10:146

Brayton KA, O'Rourke KI, Lyda AK, Miller MW, Knowles DP (2004) A processed pseudogene contributes to apparent mule deer prion gene heterogeneity. Gene 326:167-173

Bremer J, Baumann F, Tiberi C, Wessig C, Fischer H, Schwarz P, Steele AD, Toyka KV, Nave KA, Weis J, Aguzzi A (2010) Axonal prion protein is required for peripheral myelin maintenance. Nat Neurosci 13:310-318

Capellari S, Parchi P, Wolff BD, Campbell J, Atkinson R, Posey DM, Petersen RB, Gambetti P (2002) Creutzfeldt-Jakob disease associated with a deletion of two repeats in the prion protein gene. Neurology 59:1628-1630

Collinge J (2001) Prion diseases of humans and animals: their causes and molecular basis. Annu Rev Neurosci 24:519-550

Davies P, Brown DR (2008) The chemistry of copper binding to PrP: is there sufficient evidence to elucidate a role for copper in protein function? Biochem $\mathrm{J}$ 410:237-244
Flechsig E, Shmerling D, Hegyi I, Raeber AJ, Fischer M, Cozzio A, von Mering C, Aguzzi A, Weissmann C (2000) Prion protein devoid of the octapeptide repeat region restores susceptibility to scrapie in PrP knockout mice. Neuron 27:399-408

Gilch S, Spielhaupter C, Schätzl HM (2000) Shortest known prion protein allele in highly BSE-susceptible lemurs. Biol Chem 381:521-523

Goldmann W, Chong A, Foster J, Hope J, Hunter N (1998) The shortest known prion protein gene allele occurs in goats, has only three octapeptide repeats and is non-pathogenic. J Gen Virol 79:3173-3176

Grill A, Amori G, Aloise G, Lisi I, Tosi G, Wauters LA, Randi E (2009) Molecular phylogeography of European Sciurus vulgaris: refuge within refugia? Mol Ecol 18:2687-2699

Guerrieri F, Minicozzi V, Morante S, Rossi G, Furlan S, La Penna G (2009) Modeling the interplay of glycine protonation and multiple histidine binding of copper in the prion protein octarepeat subdomains. J Biol Inorg Chem 14:361-374

Guindon S, Gascuel O (2003) A simple, fast, and accurate algorithm to estimate large phylogenies by maximum likelihood. Syst Biol 52:696-704

Haigh CL, Wright JA, Brown DR (2007) Regulation of prion protein expression by noncoding regions of the Prnp gene. J Mol Biol 368:915-927

Jeong BH, Nam JH, Lee YJ, Lee KH, Jang MK, Carp RI, Lee HD, Ju YR, Ahn JS, Park KY, Kim YS (2004) Polymorphisms of the prion protein gene (PRNP) in a Korean population. J Hum Genet 49:319-324

Kim DW, Chae SH, Kang BR, Choi SH, Kim A, Woo S, Park HS (2008) Comparative genomic analysis of the whale (Pseudorca crassidens) PRNP locus. Genome 51:452-464

Kovacs GG, Budka H (2009) Molecular pathology of human prion diseases. Int J Mol Sci 10:976-999

Malaise M, Schätzl HM, Burkle A (2008) The octarepeat region of prion protein, but not the TM1 domain, is important for the antioxidant effect of prion protein. Free Radic Biol Med 45: 1622-1630

Martin R, Gallet PF, Rocha D, Petit D (2009) Polymorphism of the prion protein in mammals: a phylogenetic approach. Recent Pat DNA Gene Seq 3:63-71

Mitteregger G, Vosko M, Krebs B, Xiang W, Kohlmannsperger V, Nölting S, Hamann GF, Kretzschmar HA (2007) The role of the octarepeat region in neuroprotective function of the cellular prion protein. Brain Pathol 17:174-183

O'Rourke KI, Spraker TR, Hamburg LK, Besser TE, Brayton KA, Knowles DP (2004) Polymorphisms in the prion precursor functional gene but not the pseudogene are associated with susceptibility to chronic wasting disease in white-tailed deer. J Gen Virol 85:1339-1346

Oshida T, Masuda R (2000) Phylogeny and zoogeography of six squirrel species of the genus Sciurus (Mammalia, Rodentia), inferred from cytochrome B gene sequences. Zoolog Sci 17: 405-409

Perry RT, Go RC, Harrell LE, Acton RT (1995) SSCP analysis and sequencing of the human prion protein gene (PRNP) detects two different $24 \mathrm{bp}$ deletions in an atypical Alzheimer's disease family. Am J Med Genet 60:12-18

Posada D (2008) jModelTest: phylogenetic model averaging. Mol Biol Evol 25:1253-1256

Premzl M, Gamulin V (2009) Positive selection in prion protein. J Mol Evol 68:205-207

Rongyan Z, Xianglong L, Lanhui L, Xiangyun L, Fujun F (2008) Evolution and differentiation of the prion protein gene (PRNP) among species. J Hered 99:647-652

Sekercioglu CH (2004) Prion diseases and a penchant for brains. Science 305:342-343 
Sørensen AB, Duch M, Jørgensen P, Pedersen FS (1993) Amplification and sequence analysis of DNA flanking integrated proviruses by a simple two-step polymerase chain reaction method. J Virol 67:7118-7124

Steele AD, Lindquist S, Aguzzi A (2007) The prion protein knockout mouse: a phenotype under challenge. Prion 1:83-93

Stevens DJ, Walter ED, Rodríguez A, Draper D, Davies P, Brown DR, Millhauser GL (2009) Early onset prion disease from octarepeat expansion correlates with copper binding properties. PLoS Pathog 5:e1000390

van Rheede T, Smolenaars MM, Madsen O, de Jong WW (2003) Molecular evolution of the mammalian prion protein. Mol Biol Evol 20:111-121
Viles JH, Klewpatinond M, Nadal RC (2008) Copper and the structural biology of the prion protein. Biochem Soc Trans 36:1288-1292

Wang V, Chuang TC, Soong BW, Shan DE, Kao MC (2009) Octarepeat changes of prion protein in Parkinson's disease. Parkinsonism Relat Disord 15:53-58

Wopfner F, Weidenhöfer G, Schneider R, von Brunn A, Gilch S, Schwarz TF, Werner T, Schätzl HM (1999) Analysis of 27 mammalian and 9 avian PrPs reveals high conservation of flexible regions of the prion protein. J Mol Biol 289:1163-1178

Yu S, Yin S, Pham N, Wong P, Kang SC, Petersen RB, Li C, Sy MS (2008) Ligand binding promotes prion protein aggregation-role of the octapeptide repeats. FEBS J 275:5564-5575 